\title{
PEMANFAATAN BUAH APEL (Malus sylvestris MILL.) LEWAT MATANG SEBAGAI SUBSTRAT NATA DE APPLE
}

\author{
Achmad Gazali ${ }^{1, *}$, Anita Munawwaroh ${ }^{2}$ \\ ${ }^{1,2}$ Ikip Budi Utomo, Malang, Indonesia \\ *Email: achmadgazali88@gmail.com
}

\begin{abstract}
Malang and Batu are territories for the apel production in Indonesia. Overripe and rejected apples become trash only. So, it's needed to make a solution for raising value. The reseach was conducted in Mei-Juli 2016, the objective of this study was to utilize the overripe apple as a substrates of nata de apple. Apples were gotten from malang apple shop. Samples were washed and mixed with water until 50\%:50\% of ratio (cider A), after that, filtering cider with a gause. Cider was diluted by watering again until achieving 75\%:25\% (cider B) and $87,5 \%: 12,5 \%$ (cider C) of ratio. All ciders were heated to avoid a bacteria contaminant. $100 \mathrm{ml}$ each of cider is put into specific bottles and added with $10-20 \mathrm{ml}$ of Gluconobacter xylinus. The ciders were incubated at room temperature. The result of this study showed that the growth of nata de apple on cider $\mathrm{A}(1.27 \pm 0,9 \mathrm{~cm})$ is thicker than $\mathrm{B}(1.27 \pm 0,9 \mathrm{~cm})$ and nata on cider $\mathrm{B}$ was thicker than $\mathrm{C}(0.13 \pm 0,1 \mathrm{~cm})$. The nata weight was 66.7gr for A, 43gr for B and 4.2gr for C. The residual liquid fermentation test showed that the total acid 0.4 $\mathrm{mg} / \mathrm{ml}$ for $\mathrm{A}, 0.3 \mathrm{mg} / \mathrm{ml}$ for $\mathrm{B}$ and $0.1 \mathrm{mg} / \mathrm{ml}$ for C. The sugar reduction degree was $17,15 \mathrm{mg} / \mathrm{ml} \mathrm{of} 32.4$ $\mathrm{mg} / \mathrm{ml}$ for A, $8 \mathrm{mg} / \mathrm{ml}$ of $26.4 \mathrm{mg} / \mathrm{ml}$ for B, and no sugar reduction of $6.3 \mathrm{mg} / \mathrm{ml}$ for C. It could be concluded that the cider A resulting the best subrate of nata de apple.
\end{abstract}

Keywords: Apple; Nata; Utilization.

\section{PENDAHULUAN}

Malang dan Kota Batu merupakan daerah utama penghasil apel di Indonesia. Sekitar $80 \%$ populasi tanaman apel di Jawa Timur terkonsentrasi di Kabupaten Malang dan Kota Batu (Irawan, 2007; Sellitasari dan Suryanto, 2013). Berdasarkan data Dinas Pertanian dan Kehutanan Kota Batu, pada tahun 2010, jumlah produksi apel di Kota Batu mencapai 2.574.852 pohon dengan produktivitasnya mencapai $17 \mathrm{~kg} /$ pohon (Kusumawati, dkk, 2013). Apel merupakan buah dengan kandungan gula total yang cukup tinggi, yaitu sekitar $14.19 \pm 1.18 \mathrm{~g} / 100 \mathrm{ml}$ (Wosiacki et al., 2007).

Sebagian besar produksi apel diperjual belikan dalam bentuk buah segar untuk langsung dikonsumsi. Namun seringkali terdapat sebagian buah yang kurang memenuhi standar, seperti buah yang jatuh dari pohonnya atau dikenal dengan apel reject, buah apel yang terlalu matang atau lewat matang dan juga buah dengan penampilan yang kurang baik, sehingga tidak laku untuk dijual ke pasar. Bahkan karena banyaknya jumlah apel reject, petani apel di Kota Batu hanya dapat memanen dan menjual secara optimal sekitar 60\%-70\% dari apel yang di produksi (Kusumawati dkk, 2013). Buah yang kurang memenuhi standar penjualan tersebut memiliki nilai ekonomi sangat rendah bahkan hanya dibuang menjadi sampah. Oleh karena itu diperlukan suatu solusi alternatif untuk menaikan nilai ekonomi buah apel tersebut. Apel memiliki kadar glukosa yang cukup tinggi dan berpotensi sebagai substrat pembuatan nata. Belum banyak informasi yang mengulas tentang pemanfaatan apel dari Malang dan Batu sebagai substrat pembuatan nata. Nata merupakan makanan berserat tinggi yang disintesis dari bahan organik dengan kadar glukosa tinggi (Budiyanto, 2000; Mikkelsen et al.,2009; Cassarica et al., 2013). Gluconacetobacter xylinus mengubah glukosa menjadi lapisan selulosa ekstraselular dan secara bertahap menutupi permukaan membentuk nata. (Hugund and Gupta., 2010; Prades et al., 2011; Sutanto, 2012; Jumeri et al., 2014). Tujuan penelitian ini adalah memanfaatkan buah apel lewat matang dan kurang laku jual sebagai substrat pembuatan Nata De Apple. Buah apel lewat matang dapat dimanfaatkan menjadi substrat alternatif pembuatan nata, menghasilkan diversifikasi produk inovasi berupa nata de apple dari kota Malang.

\section{METODOLOGI PENELITIAN Preparasi Sampel}

Sampel buah apel lewat matang didapatkan dari toko dan penjual buah apel malang, kemudian apel dibersihkan dan dibuat juice menggunakan 
blender dengan perbandingan buah apel dan air 1:1 (50\%:50\%), untuk memisahkan cairan buah apel (sari apel) dari substratnya dilakukan penyaringan menggunakan kain. $\mathrm{pH}$ sari apel diatur menjadi $\mathrm{pH}$ 3 dengan menggunakan asam asetat. Kemudian dilakukan pengenceran sehingga didapatkan konsentrasi 50\% (sari apel A), 25\% (sari apel B), $12,5 \%$ (sari apel C). Sebanyak $100 \mathrm{ml}$ sari apel dimasukkan ke dalam botol kaca steril dengan diameter $5 \mathrm{~cm}$ dan tinggi $11 \mathrm{~cm}(350 \mathrm{ml})$, ditutup dengan penutup. Sterilisasi botol kaca dilakukan dengan menuangkan air mendidih ke dalam botol dan didiamkan selama 10 - 15 menit.

Inokulasi starter bakteri Gluconobacter xylinus dilakukan setelah semua botol percobaan terisi dengan masing-masing sari apel. Medium yang sudah diinokulasi diinkubasi pada suhu ruangan $\left(20-25^{\circ} \mathrm{C}\right)$ selama masa tumbuh (15-25 hari). Pengamatan dilakukan setiap 2 hari sekali dimulai dari awal inokulasi starter bakteri sampai nata terbentuk maksimal. Setelah nata terbentuk dilakukan analisis nata de apel yang meliputi: ketebalan nata, pengukuran berat basah nata. Selain analisis nata juga dilakukan analisis proksimat dan analisis cairan medium yang meliputi kadar gula reduksi (sebelum dan sesudah pertumbuhan nata) dan kadar asam total. Percobaan dilakukan sebanyak 3 kali ulangan.

\section{Analisis proksimat}

Analisis proksimat meliputi analisis kadar air, kadar protein, serta gula reduksi. Analisis proksimat dilakukan pada sampel cairan buah yang digunakan sebagai media pertumbuhan dengan konsentrasi 50\% (b/v). Analisis proksimat diujikan di Balai Penelitian Sayur dan Tanaman (Balitsa) Lembang.

\section{Analisis Nata De Apple \\ 1. Ketebalan nata}

Analisis untuk nata de apple yang dihasilkan berupa pengukuran pertambahan ketebalan nata menggunakan penggaris. Pengukuran dilakukan setiap 48 jam bersamaan dengan pengamatan nata selama masa tumbuh.

\section{Pengukuran berat basah}

Pengukuran berat basah dilakukan setelah panen dengan menimbangnya menggunakan timbangan analitik.

\section{Analisis cairan sisa fermentasi}

Analisis cairan sisa fermentasi yang terdapat di bagian bawah media yang tidak membentuk nata meliputi kadar gula reduksi dengan menggunakan metode Luff Schoorl yang resmi ditetapkan oleh BSN dalam SNI 01-2891-1992 dan kadar asam total dengan metode titrasi asam basa, Percobaan dilakukan sebanyak 3 kali ulangan.

\section{HASIL DAN PEMBAHASAN Analisis proksimat}

Sari buah apel malang memiliki kadar air yang tinggi yaitu 96,61\%. Kadar protein sampel buah apel lewat matang sebesar $0,14 \%$ dan gula reduksi 5,38 \% (Tabel 1.). Hasil analisis proksimat sari buah apel lewat matang (Tabel 1.) menunjukkan bahwa sari apel berpotensi sebagai substrat alternatif dalam pembentukan nata.

\begin{tabular}{cc} 
Tabel 1. Analisis proksimat sari apel \\
\hline Kandungan gizi & Kadar $(\%)$ \\
\hline Air & 96,61 \\
Protein & 0,14 \\
Gula reduksi & 5,38 \\
\hline
\end{tabular}

Pengamatan pertumbuhan Nata de apple dilakukan terhadap sari apel dengan 3 tingkatan pengenceran yaitu 50\% (Sari apel A), 25\% (Sari apel B), dan 12,5\% (Sari apel C) dengan masing- masing 3x ulangan. Masing masing sari apel dengan tingkat pengenceran berbeda, memiliki kadar gula reduksi yang berbeda seperti ditunjukkan pada tabel 2 .

\section{Tabel 2. Kadar gula reduksi pada berbagai konsentrasi cairan buah apel

\begin{tabular}{cc}
\hline $\begin{array}{c}\text { Konsentrasi cairan } \\
\text { buah apel }\end{array}$ & Kadar gula reduksi (mg/mL) \\
\hline $50 \%($ Sari apel A) & 32,4 \\
$25 \%($ Sari apel B) & 26,4 \\
$12,5 \%$ (Sari apel C) & 6,3 \\
\hline
\end{tabular}

Sari apel A memiliki kadar gula reduksi 32,4 $\mathrm{mg} / \mathrm{ml}$, Sari apel B memiliki kadar gula reduksi $26,4 \mathrm{mg} / \mathrm{ml} \mathrm{mg/ml}$. Sari apel C memiliki kadar gula reduksi $6,3 \mathrm{mg} / \mathrm{mL}$. Sari buah yang mengandung kadar glukosa tinggi, dapat menjadi sumber karbon substrat bagi pertumbuhan bakteri Gluconobacter 
xylinus untuk membentuk nata (Hungund and Gupta, 2010). Glukosa yang terdapat pada sari apel dikonversi menjadi selulosa oleh bakteri tersebut. Penggabungan unit - unit glukosa terjadi pada gugus terminal glukosa melalui ikatan glikosida $B$ 1,4 sehingga terjadi pemanjangan dan terbentuk polimer nata (Waites et. al., 2006). Selulosa terbentuk perlahan berupa lapisan pelikel tipis kemudian membentuk suatu jalinan yang terus menebal menjadi lapisan nata seiring dengan bertambahnya masa inkubasi (Jonas and Farah, 1998).

Data pada tabel 2. menunjukkan bahwa sari apel A mengandung gula reduksi tertinggi. Hal ini menunjukkan bahwa sari apel A merupakan media paling baik untuk pertumbuhan Gluconoacetobacter xylinus dalam menghasilkan nata, sementara sari apel $\mathrm{B}$ dan $\mathrm{C}$ juga dapat dijadikan media pertumbuhan bakteri dengan hasil nata yang lebih rendah. Penelitian ini juga membuktikan bahwa cairan buah apel malang yang tidak laku jual dipasaran dapat digunakan sebagai media pertumbuhan bakteri penghasil nata.

\section{Analisis Nata de apple}

Gambar 1. menunjukkan proses pembentukan nata dari hari ke hari. Pada hari ke 0 terlihat pada botol kaca belum terbentuk pelikel lapisan nata pada semua sari Apel. Hal tersebut dikarenakan bakteri Gluconoacetobacter xylinus membutuhkan waktu untuk tumbuh dan beradaptasi pada media. Pada hari ke 8 sudah mulai terbentuk pelikel lapisan tipis pada permukaan botol kaca yang nampak terlihat jelas pada sari apel A dan B, sedangkan pada sari apel $\mathrm{C}$ belum terlihat secara nyata. Pada botol control (tanpa bakteri) tidak terlihat aktifitas pertumbuhan nata. Adanya perubahan pada sari apel $\mathrm{A}, \mathrm{B}$ dan $\mathrm{C}$ menunjukkan bahwa proses pembentukan nata dari glukosa menjadi ekstraseluler selulosa sedang berlangsung. Sel Gluconoacetobacter xylinus menggunakan glukosa sari apel dan menggabungkannya dengan asam lemak, kemudian dengan bantuan enzim mempolimerisasi glukosa menjadi polimer selulosa (Jonas and Farah, 1998; Rizal et al., 2013).

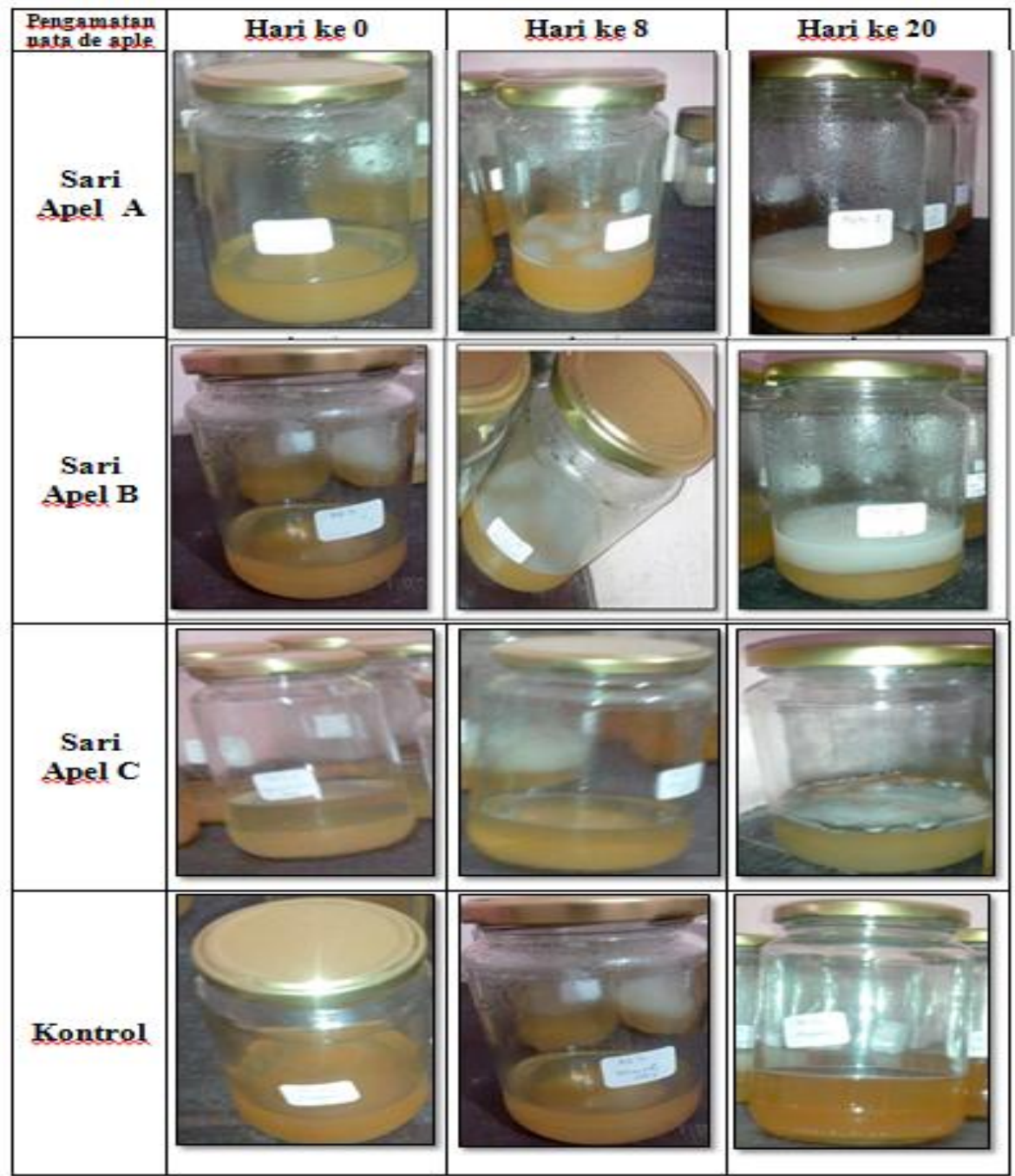

Gambar 1. Hasil pengamatan sari apel hari ke-0, 8, dan 20 
Pengamatan pada hari ke 20 menunjukkan adanya lapisan pelikel di atas permukaan medium yang menebal membentuk nata. Nata yang mengapung dipermukaan medium disebabkan oleh adanya gas karbon dioksida yang dihasilkan secara lambat oleh bakteri Gluconobacter xylinus, sehingga nata terdorong ke permukaan medium (Rizal et al., 2013). Pada hari ke 22 tidak ada lagi penebalan nata. Hal tersebut diduga karena kandungan glukosa pada medium sudah habis sehingga tidak ada lagi substrat glukosa yang dapat dikonversi menjadi nata. Budhiono et al.,(1999) menyatakan bahwa pembentukan nata dipengaruhi oleh konsentrasi gula dalam medium pertumbuhan.
Konsentrasi sari apel menentukan produk akhir ketebalan dan berat nata yang dihasilkan. Berdasarkan perhitungan rata-rata pada pengamatan 3 kali ulangan didapatkan bahwa pertumbuhan nata de apel lebih tebal pada sari apel A dengan tebal maksimal 2,13 $\pm 0,3 \mathrm{~cm}$ dan pertumbuhan paling cepat pada hari ke $12-14(0,4 \mathrm{~cm})$, pertumbuhan nata de apel berikutnya diikuti oleh sari apel B dengan tebal maksimal $1,27 \pm 0,9$, pertumbuhan nata paling cepat terjadi pada hari ke $8-10(0,4 \mathrm{~cm})$. Pertumbuhan apel paling rendah terjadi pada sari apel $C$ dengan tebal maksimal $0,13 \pm 0,1 \mathrm{~cm}$. (Gambar 2.).

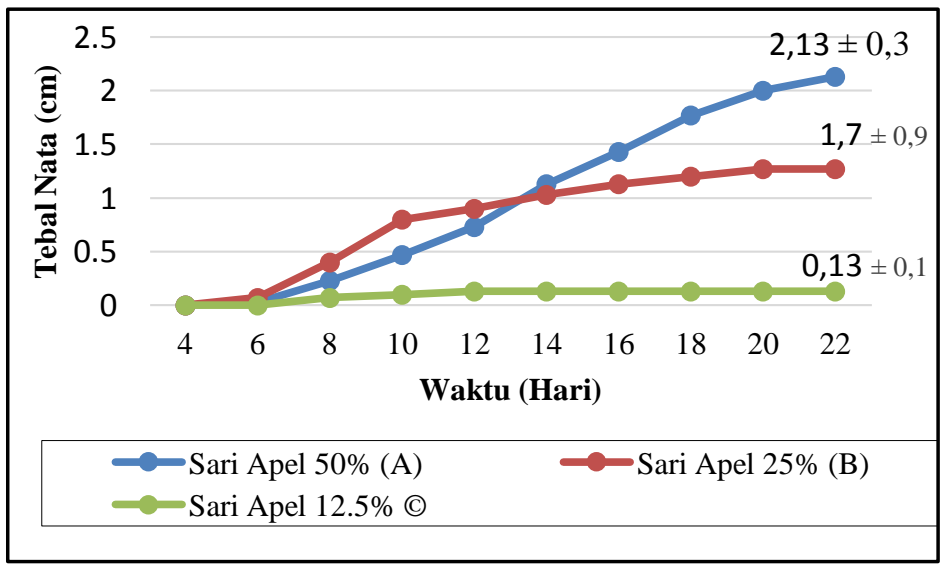

Gambar 2. Tebal nata de apple

\section{Pengukuran berat basah}

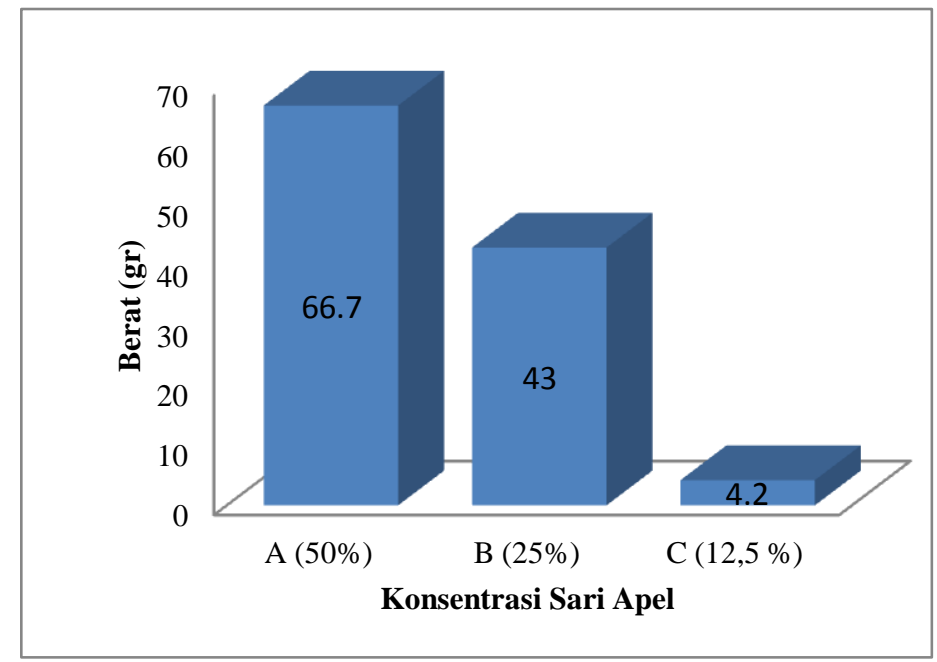

Gambar 3. Berat basah nata de apple

Berdasarkan hasil pengukuran berat basah nata de apple (Gambar 3.) didapatkan bahwa berat nata pada sari apel A sebesar 66.7gr, sari apel B sebesar 43gr dan pada sari apel C 4.2gr. Hasil pengamatan dapat menunjukkan bahwa berat nata paling tinggi terjadi pada sari apel A diikuti sari apel B dan sari apel C. Hal ini membuktikan bahwa semakin banyak jumlah pengenceran maka semakin berkurang kadar glukosa pada volume larutan yang sama, akibatnya konsentrasi glukosa yang dapat dikonversi menjadi nata semakin rendah. Begitu juga sebaliknya semakin tinggi konsentrasi sari apel 
semakin tinggi kadar glukosa yang dipolimerisasi

dihasilkan

(Budhiono

et

al., 1999).

menjadi selulosa semakin berat nata yang

\section{Analisis Cairan Sisa Fermentasi \\ Kadar gula reduksi}

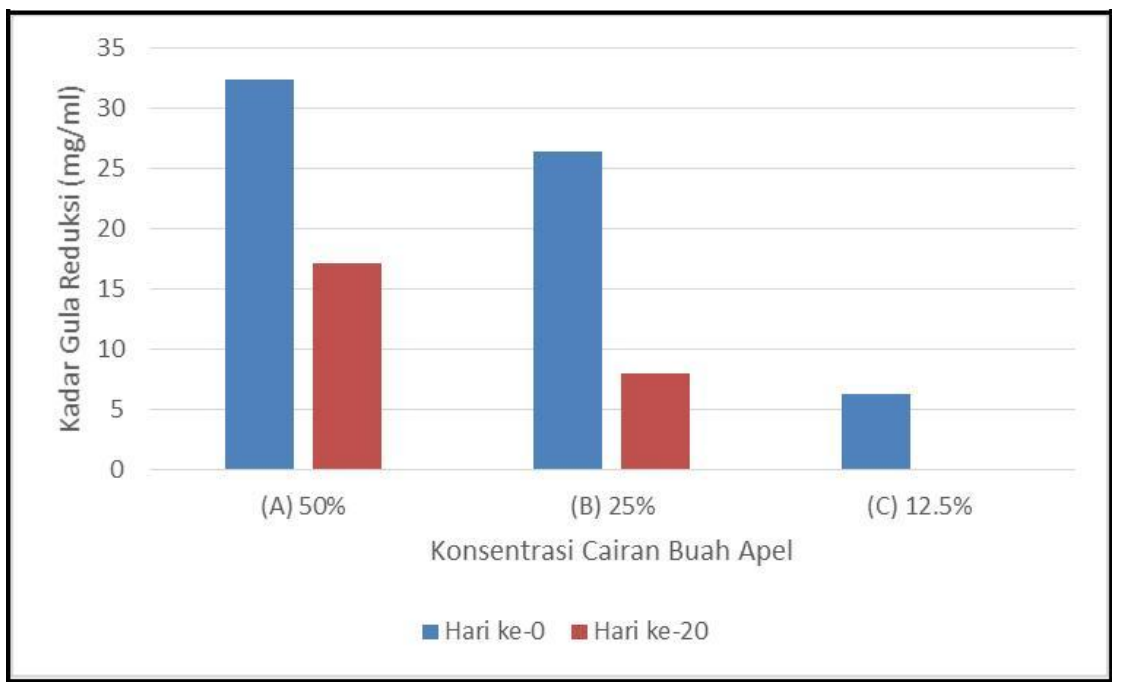

Gambar 4. Penurunan kadar gula reduksi setelah fermentasi

Terjadi penurunan kadar gula reduksi pada hari ke 20 (Gambar 4). Pada hari ke 0 sari apel A mengandung gula reduksi $32.4 \mathrm{mg} / \mathrm{ml}$, setelah hari ke 20, kadar gula reduksinya menurun menjadi $17.15 \mathrm{mg} / \mathrm{ml}$. Sari apel B pada mengandung gula reduksi $26.4 \mathrm{mg} / \mathrm{ml}$ hari ke 0 , terjadi penurunan menjadi $8 \mathrm{mg} / \mathrm{ml}$ pada hari ke 20 . Sedangkan pada sari apel $\mathrm{C}$, kadar gula residu pada hari ke 06,3 $\mathrm{mg} / \mathrm{ml}$ dan pada hari ke 20 kadar gula reduksi telah habis. Penurunan kadar gula reduksi tersebut dikarenakan Gluconoacetobacter xylinus telah mengkonversi glukosa menjadi selulosa (nata), sehingga semakin hari kadar gula reduksi pada medium semakin berkurang.

\section{Kadar asam total}

Tabel 4. menujukkan kadar asam total pada berbagai konsentrasi cairan sisa fermentasi buah apel. Sari apel A memiliki kadar asam total $0,4 \mathrm{mg} /$ $\mathrm{ml}$, diikuti sari apel B $0,3 \mathrm{mg} / \mathrm{ml}$ dan sari apel C 0,1 $\mathrm{mg} / \mathrm{ml}$. Hal ini membuktikan bahwa semakin besar pengenceran semakin sedikit kadar asam total.

Tabel 4. Kadar asam total pada berbagai konsentrasi cairan buah apel

\begin{tabular}{cc}
\hline $\begin{array}{c}\text { Konsentrasi cairan } \\
\text { buah apel }\end{array}$ & $\begin{array}{c}\text { Kadar asam total } \\
(\mathbf{m g} / \mathbf{m l})\end{array}$ \\
\hline $50 \%$ (Sari apel A) & 0,4 \\
$25 \%$ (Sari apel B) & 0,3 \\
$12,5 \%$ (Sari apel C) & 0,1 \\
\hline
\end{tabular}

Gluconoacetobacter xylinus selain menghasilkan metabolit primer yang berupa nata, juga menghasilkan metabolit sekunder berupa asam asetat. Produk asam asetat dibentuk dari oksidasi alkohol maupun reduksi asam piruvat oleh bakteri Gluconoacetobacter xylinus. Asam piruvat diubah menjadi asetaldehid dengan bantuan tiamin difosfat dan dikatalisis oleh enzim piruvat dekarboksilase. Selanjutnya asetaldehid direduksi menjadi etanol dengan enzim alkohol dehidrogenase dan dioksidasi menjadi asam asetat yang dikatalisis oleh enzim aldehid dehydrogenase.

\section{KESIMPULAN}

Berdasarkan hasil penelitian dapat disimpulkan bahwa buah apel lewat matang dapat dimanfaatkan sebagai substrat pembuatan nata de apple. Pembentukan nata dengan tebal yang optimal terjadi pada substrat nata sari apel A $(50 \%$ sari apel) dengan tebal maksimal rata-rata 2,13 $\pm 0,3$ dan berat nata 66,7 gram.

\section{UCAPAN TERIMA KASIH}

Terima kasih penulis sampaikan kepada Direktorat Riset dan Pengabdian Masyarakat 
Direktorat Jenderal Penguatan Riset dan Pengembangan Kementrian Riset, Teknologi, dan Pendidikan Tinggi yang telah mendanai penelitian ini.

\section{DAFTAR PUSTAKA}

[1] Budiyanto, A. K. (2002). Mikrobiologi Terapan. Penerbit: Universitas Muhamadiyah Malang.

[2] Budhiono, A., Rosidi, B., Taher, H., M. Iguchi. (1999). Kinetic Aspects of Bacterial Cellulose Formation in Nata de Coco Culture System. Carbohydrate Polymers 40: 137-143.

[3] Casarica , A., Campeanu, G., Moscovici M., Ghiorghita, A., Manea, V. (2011). Improvement of Bacterial Cellulose Production by Acetobacter xylinum on Poor Quality Horticultural Substrates. Cellulose Chemistry and Technology. 47 (1-2), 61-68.

[4] Hungund.B.S. and Gupta S.G. (2010). Improved Production of Bacterial Cellulose From Gluconacetobacter persimmonis $\mathrm{GH}-$ 2. Journal of Microbial \& Biochemical Technology. 2: 127-133.

[5] Irawan. (2007). Potensi Pengembangan Tanaman Apel Berdasarkan Aspek Agroklimat di Jawa Timur. Skripsi Dep.Geofisika dan Meteorologi. FMIPA. IPB. Bogor.

[6] Jonas,R. and Farah, L.F. (1998). Production and Application of Microbial Cellulose. Polymer Degradation and Stability 59: 101106.

[7] Jumeri, P. Manggala, A. Cintiadewi, N. Khuriyati, and D. Purwadi. (2014). Feasibility Analysis of Cassava and Glucose Syrup as Alternatives Raw Materials for Industrial Nata. Agroindustrial Journal 3: 113-119.

[8] Kusumawati.R., M.A. Irawan, dan A.Purbasari. (2013). Pengaruh Perbandingan Jumlah Sarter Terhadap Proses Fermentasi Wine Apel Menggunakan Nopkor MZ-11. Jurnal Teknologi Kimia dan Industri, 2: 226-232.

[9] Mikkelsen, D., Flanagan B.M., Dykes, G.A., Gidley, M.J., (2009). Influence of Different Carbon Source on Bacterial Cellulose production by Glucoacetobacter xylinus strain ATCC 53524. Journal of Applied Microbiology 107(2):576-583.
[10] Prades.A, M. Dornier, N.Diop, and J.P. Pain. (2011). Coconut Water Uses, Composition and Properties : a review. Fruits, 67 (2): 87.

[11] Rizal, M.D., Pandiangan, D.M., Saleh A. (2013). Pengaruh dan Waktu Fermentasi Terhadap Kualitas Nata de Corn. Jurnal Teknik Kimia 19 (1): 85-91.

[12] Sellitasari.S, dan A.A Suryanto. (2013). Perbedaan Produksi tanaman apel (Malus sylvestris mill.) Pada Agroklimat yang Berbeda. Jurnal Produksi Tanaman. 1 (1):

[13] Sutanto, A. (2012). Pineapple Liquid Waste as Nata de Pina Raw Material. Makara Teknologi, 16(1): 63-67.

[14] Waites, M.J; N.L Morgan; J.S. Rockey and G. Higton. (2006). Introduction of Industrial Microbiology. Blackwell Publishing Company. Victoria.

[15] Wosiacki.G, A. Nogueira, F. Denardi, and R.G Viera. (2007). Sugar Composition of Depectinized Apple Juices. Proceding Semina Ciencias Agrarias, Londrina, 28(4): 645-652. 